\title{
PREFERENCE OF LAYING HENS FOR DIFFERENT PROTEIN SOURCES IN A CAFETERIA TYPE FEEDING SYSTEM
}

\author{
J.O. ATTEH and A. AJAKAIYE \\ Department of Animal Production, University of Ilorin, Ilorin \\ Kwara State, Nigeria \\ Received 9 July, 1990 Accepted 12 October, 1992
}

\begin{abstract}
Laying hens (29-wk old) had access to a basal diet and one of full-fat soybeans, fish meal or blood meal during a 6-week trial to investigate their preference for different protein sources.

There was no effect of the dietary treatment on egg production, egg weight or mortality rate $(P>0.05)$. However, weight loss was different $(\mathrm{P}<0.05)$ among the treatments with the largest body weight loss observed in birds offered blood meal.
\end{abstract}

\section{INTRODUCTION}

Although the sense of taste of the domestic fowl is not as well developed as in other livestock species (Moran, 1982), chickens are known to have preference for different feed ingredients (Kare and Pick, 1960; Lilburn, et $a l ., 1981$ and Hussein et al., 1983). The chicken's preference for certain food stuffs may be associated with the need to maintain minimal amounts of certain nutrients in the body. Thus, calcium deprived chickens can accurately identify calcium-supplemented diets under ordinary circumstances (Joshua and Mueller, 1979). Also, zinc deficient fowl would appear to have increased taste because they can rapidly discriminate between feeds differing in their content of this nutrient (Hughes and Dewar, 1971). Feed preference by chickens may be associated with palatability regardless of nutritional value or rather the chicken has become accustomed to the feed because of an associated sense of well-being (Moran, 1982). However, Kare and Medway (1959), reported that swectness as we recognize it, is of no importance in the fowl,

Nigerian Journal of Animal Production 20 (1993) suggesting that factors other than taste would influence feed discrimination by the chicken.

There is a growing interest in the preference of chickens for different feed ingredients. Gentle (1972) investigated the preference of chickens for mineral and carbohydrate sources, while Lilburn et al. (1981) concentrated their work on distillers dried grains with solubles. Also Cantor and Johnson (1982), and Hussein et al. (1983) reported results of experiments designed to investigate the effects of unidentified growth factor sources on food preference by chickens. In reports cited above, test ingredients were incorporated at various percentages of the diet. The study reported here was undertaken to investigate the preference of laying hens for different protein sources in a cafeteria type feeding system where a basal diet and various protein sources were separated.

\section{MATERIALS AND METHODS}

Ninety six, Black Olympia laying hens of a commercial strain, accommodated in an opensided deep-litter house were used for this study. The laying hens, (29 weeks old) were weighed, and then randomly assigned to the treatments.

Birds fed a commercial diet (15\% CP) served as control while the other birds were allowed access to the basal diet (Table 1) and fish meal, ground toasted full-fat soybeans or blood meal (Table 2). Thus, there were four treatments and three replicate pens of eight birds each.

The control diet, basal diet and the different protein sources and water were supplied ad libitum while the natural photoperiod was approximately $12 \mathrm{~h}$ during the trial period that 
TABLE 1 COMPOSITION OF BASAL DIET $(\mathrm{G} / \mathrm{KG})$

Maize

802.4

Maize Offal

80.2

Oyster shell

82.7

Bone meal

28.4

Salt

3.4

Premix $^{2}$

Supplied/kg of basal diet: $2.8 \mathrm{mg}$ retinol, $50 \mu \mathrm{g}$ cholecalciferol; $11 \mathrm{mg}$ DL-trocopheryl acetate, $2 \mathrm{mg}$ menadione, $7 \mathrm{mg}$ calcium pantothenate, $7 \mathrm{mg}$ riboflavin, $20 \mathrm{mg}$ niacin, $8 \mu \mathrm{g}$ cyanocobalamin, $1.5 \mathrm{mg}$ folic acid, $0.3 \mathrm{mg}$ biotin, $300 \mathrm{mg}$ choline chloride, $125 \mathrm{mg}$ ethoxyquin, $80 \mathrm{mg}$ manganese, $50 \mathrm{mg}$ zinc, $5 \mathrm{mg}$ copper, $25 \mathrm{mg}$ iron.

TABLE 2 ANALYSED CONTENT OF COMMERCIAL AND BASAL DIETS AND PROTEIN SOURCES $(\mathrm{g} / \mathrm{kg})$

\begin{tabular}{llcccc}
\hline & Commercial & Basal & \multicolumn{2}{l}{ Fish Meal Soybean } & Blood meal \\
Dry matter & 923.1 & 920.4 & 976.2 & 918.2 & 913.0 \\
Crude protein & 150.0 & 75.0 & 609.1 & 408.0 & 800.9 \\
Crude fat & 67.1 & 45.2 & 100.9 & 199.2 & 10.2 \\
\hline
\end{tabular}


lasted six weeks. Weekly intake of the control diet, the basal, and the different protein sources were determined by differences in quantity supplied remaining after each week. Egg production was recarded throughout the trial and on two consecutive days each weck, eggs were collected for weighing. At the conclusion of the trial, the birds were weighed.

Data collected were subjected to analysis of variance using the model for complete randomized design (Steel and Torrie, 1980). Means of response variables having a significant F-test were further subjected to Duncan's multiple range test (Duncan, 1955).

\section{RESULTS}

The performance of the laying hens as influenced by the dietary treatments is shown in Table 3. There was no difference in the quantity of the basal feed consumed $(P>.05)$. I However, more fish meal was consumed than the other sources of protein $(\mathrm{P}<.05)$. There was no significant variation in the average daily total (basal + protein supplement) feed intake by birds fed the different protein sources. There was no significant effect of the treatments on egg production, egg weight or feed per dozen eggs $(P>05)$. All the birds used in the trial, including those fed the commercial diet, lost weight, although birds having access to blood meal as the source of protein lost more weight than other birds $(P<.05)$. Although there was no significant variation in overall mortality rate $(P>.05)$, the number of birds dying as a result of cannibalism was higher in the group with access to blood meal $(\mathrm{P}<.05)$.

There was variation in the weekly trend for consumption of the basal feed, protein supplements and total intake During the first week of the trial, birds of all treatments consumed comparable quantities of the basal diet (Figure 1). The consumption of the basal diet by birds having access to fish meal, reduced drastically during the second week and thereaftcr increased to a peak by the fifth week. On the other hand, birds having aceess to soybean generally reduced the consumption of the basal diet from the second week to the end of the trial. The consumption of the basal diet by birds with access to blood meal increased up to the second weck and thereafter decreased, although there was a small increase between the third and fourth week of the trial.

Consumption of the different protein supplements was low in the first weck of the trial (Figure 2). There was a significant increase in the consumption of fish meal during the second week, reaching a peak at the fifth week of the trial. There was a slight decrease in the second week, followed by a steady increase in the consumption of soybeans. Birds reduced their consumption of blood meal from the first to second week of the trial and thereafter rejected this protein supplement.

Figure 3 shows the weekly trend in the average daily intake of the total feed (basal + protein supplement). While the average daily feed intake of birds fed the commercial diet remained relatively constant during the trial, that of the birds having access to blood meal, showed a trend similar to the basal intake. Feed intake by birds having access to fish meal and increased with increase in time period from the first week of the trial. Total feed intake by birds having access to soybean followed a trend similar to intake of the basal, but moderated by the gradual increase in consumption of soybeans from the second week of the trial.

\section{DISCUSSION}

The different protein sources had no influence on the consumption of the basal diet, which was essentially a source of energy, minerals and vitamins for the bird There was a definite preference by laying hen: in this trial for fish meal, compared to soybeans or blood meal. This observation agrees with earlicr reports (Cantor and Johnson, 1983; 


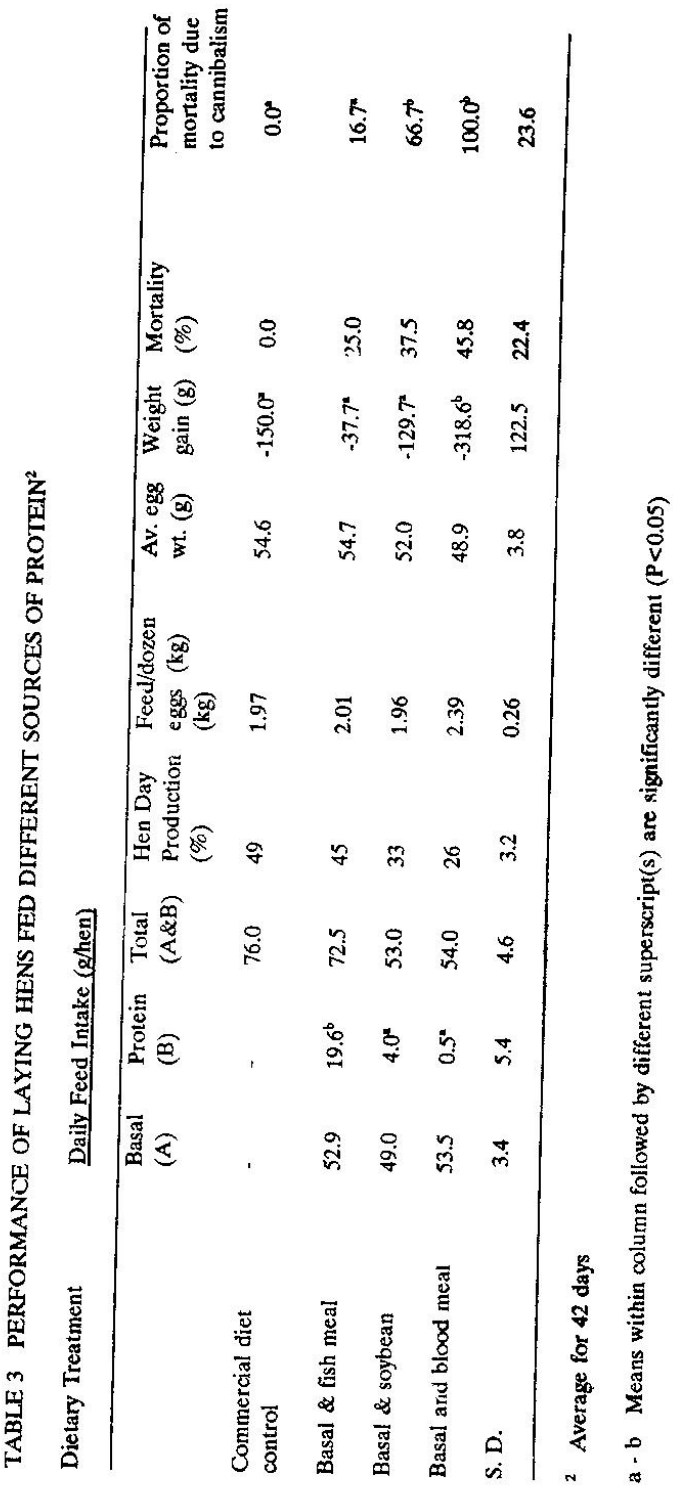


Average basal feed intake ( $\mathrm{g} / \mathrm{hen} /$ day)

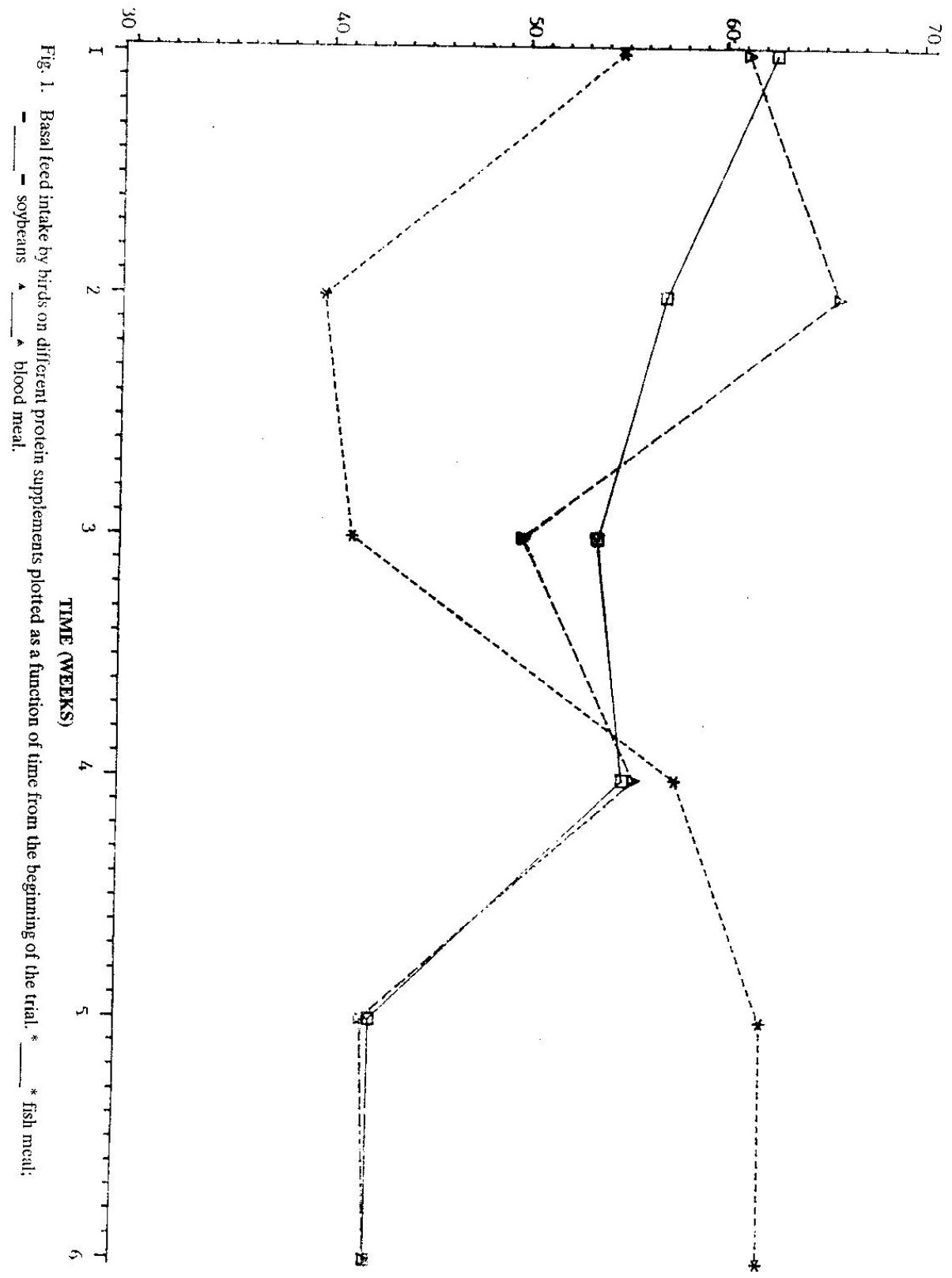


PRIIIIRIINCI: ()F I AYING IIENS FOR PROTEIN SOURCES

Average protein supplement intake ( $g /$ hen/day).

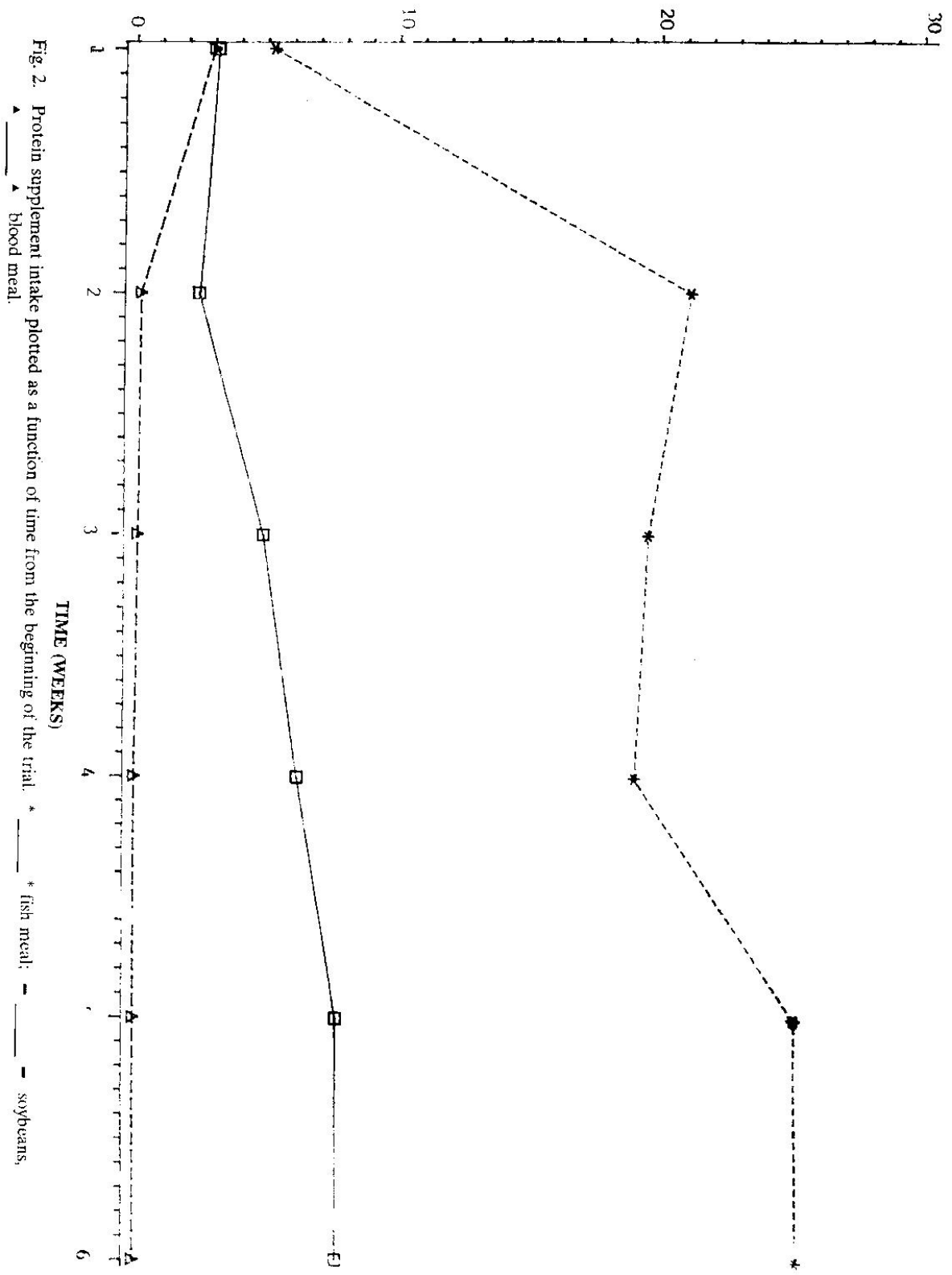


Average feed intake ( $g /$ hen/day).

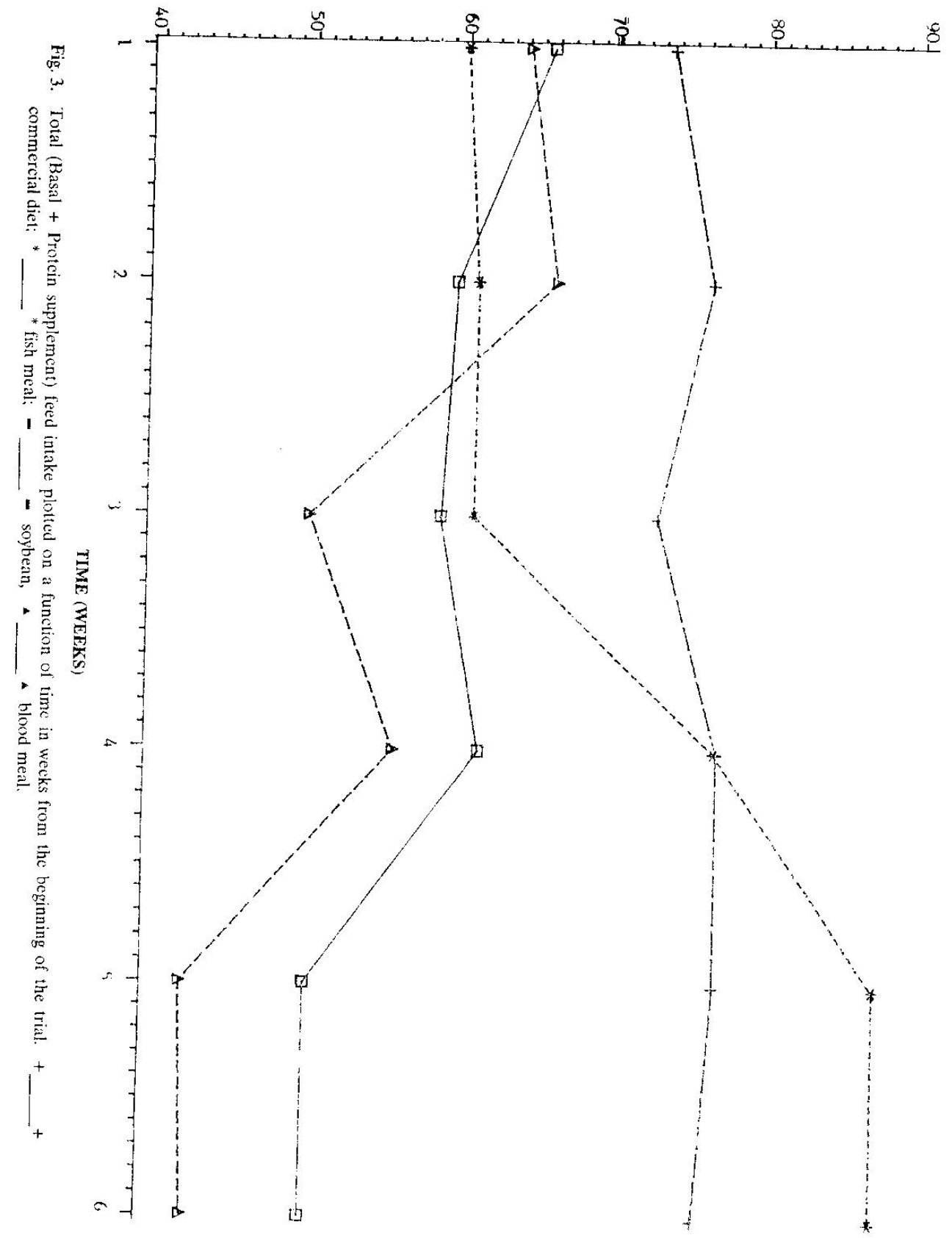


IIussein et al., 1983) showing similar preference for diets with fish meal than for a control diet without fish meal. The preference for fish meal could be associated with the fact that it supplies both guantity and quality protein needed to compensate for the protein that was deficient in the basal diet. Although birds having access to other protein sources had a similar problem of protein deficiency in their basal diet, consumption of blood meal was low because this protan is not only unpalatable, it is aiso highly deficient in the essential amino acidi isoleucine (Scott et al., 1982). The low consumption of soybeans could be due possibly to residual trypsin inhibitor in the beans.

The average daily intake sy tirds having access to the commercial ceed, fish meal, soybeans and blood meal were 11.40, 15.71, 5.32 and $4.43 \mathrm{~g}$ respectively. While the protein intake by birds having access to fish meal was adcquate for laying hens; those for birds fed soybeans or blood meal were grossly inadequate, compared to NRC (1984) standards. The fact tha: 100 and $67 \%$ of the mortality observed $1 \mathrm{a}$ sirds fed blood meal and soybeans respectiv ly wer; "ue to cannibalism would suggesi an attenpt by these birds to compensate for the protein deficiency in the basal diet. Observations during the trial revealed that cannibalism was initiated at the time of oviposition with vent pecking.

The body weight loss by all the birds used in this trial indicated that egg production was at the expense of body reserves, although the extent of body reserve depletion was higher for the birds fed blood meal than for the other groups. Calculated daily energy intake by birds having access to the commercial diet, fish meal, soybean and blood mea were $0.85,0.77$, 0.57 and 0.56 , MJ respectively. These are suboptimal energy for laying hens (Scott et al., 1982). Thus weight loss followed a trend similar to the daily protein and energy intake. Birds fed the commercial diet and those fed fish meal tended to have similar egg production and egg weight which were greater than those of birds fed soybeans or blood meal.

Analysis of the weekly intake of the basal diet ast the different protein sources showed that it tock at least a week for birds to assess the cuality of their protein supplement and respond acorrilingly. For birds fed fish meal, the recognition of a high quality protein was accompanied iy a sharp increase in its intake. On the other hand, birds fed blood meal on recognizing the poor quality protein reduced its intake and by the end of the second week completely rejected this protein supplement. In place of blood meal, birds in this group resorted to getting protein from pen mates. All the mortality in this group was due to cannibalism which started in the third week of the trial, shortly after the birds stopped consuming the bloed meat. Although the recognition of soybeans was followed by a slight decrease in its consumption, there was a subsequent increase in soybean intake, which was not sufficient to mce: their daily protein requirements. Here sin, jirds apparently resorted to cannitaliswi as a means of getting additional proteis.

It is concluded 3 this study that laying hens are able to biscern various protein supplement, their reaction to the protein supplements vared tepe ding on the quality of the protein. In this study, the order of preference of the protein sources was fish meal, soybeans and blood meal. It can also be inferred from the present study that deficiency of quality proteici would predispose l-ying hens to cannibalisri.

\section{ACKNOWLE ${ }^{\text {GEMENTS }}$}

This work was supported by a grant from the University of Ilorin Senate Research Committee. We also thank HAF Agricultural Enterprises Ilorin, for the use of their facilities. 
RFIFRENCES

CANTOR, A. H. \& J JHINSON, T. H. (1982) fiflects if unidentified growth factor sources of foud preference of chicks. Pender Science 61: 1371 (abstract).

CANTOR. A. II. \& JOHNSON, T. H. (1983) The effect of diet upon feed preference of broiler chicks. Poultry Science 62: 1339 (absiract).

DUNC $\triangle N$, D. B. (1955) Multiple range and multiple I' tests. Biometrics 11: 1-42.

GENTILE, M. J. (1972) Taste preference in the chicken (Gallus domestics L). British Poultry Science 13: 141-155.

IIUGIIES, B. O. \& DEWAR, W. A. (1971) A specific for zinc in zinc-depleted domestic fowls. British Poultry Science 12: 255-258.

HISSSIIN, A. S., CANTOR, A. H. \& JOIINSON, T. H. (1983) The effect of intact and fat extracted fish solubles and meal and fish oil on feed preference and performance of broiler chicks. Poultry Science 62: 1437 (abstract).

JOSIIUA, J. G. and MUELLER, W. J. (1979) The development of a specific appetite for calcium in growing broiler chicks. British Poultry Science 20: 481 - 490.

KARE, M. R. \& MEDWAY, W. (1959) Discrimination between carbohydrates by the fowl. Poultry Science 38: $119-1127$.
KARE, M. R. \& PICK, H. L. (1960) The influence of the sense of taste on feed and fluid consumption. Poultry Science 39: 697 - 705.

LILBURN, M. S., JENSEN, L. S. \& AKIBA, Y. (1081) Preference of broiler chicks for diets containing distillers dried grains with solubles. Poultry Science 60: 1605 (abstract).

MORAN, E. T. (1982) Comparative Nutrition of Fowl and Swine: The Gastrointestinal Systems. pp. $30-40$ (Guelph, E. T. Moran, Jr.)

NATIONAL RESEARCH COUNCIL (1984) Nutrient Requirements of Poultry. 8th edn, pp. 12 (Washington, D. C., National Acadcmy of Sciences).

SCOTT, M. L., NESHEIM, M. C. \& YOUNG, R. L. (1982) Nutrition of the chicker: 3rd edn, pp. 47, 450 (Ithaca, New York, M.L. Scott and Associate $\mathrm{T}$ ublishers).

STEEI, R. G. D. \& TORRIE, J. H. (1980) Principles and Procedures of Statistics: A Biometrical Approach, 2nd edn, pp. 137 - 171: (New York, McGraw-IIall Book Company). 